The law was subsequently changed to make possession of the plant illegal. Thus unless the Act is amended to name the psilocybin mushroom possession is legal.

Apparently increasing numbers of teenagers and others are harvesting and eating the mushrooms. ${ }^{2}$ Doctors should therefore be aware of possible long-term side effects of such agents. One of these is the flashback phenomenon described by about $5 \%$ of LSD users. ${ }^{3-5}$

The development of severe and uncharacteristic anxiety symptoms, as in the present case, may be another.

I am grateful for the help of Dr I Brockington and Dr C Hyde, Withington Hospital, and Dr G S Taylor (botany), Manchester University.

${ }^{1}$ Hyde, C, et al, British fournal of Psychiatry, 1978, 132, 602.

2 Manchester Evening News, 16 October 1978, p 1.

${ }^{3}$ Horowitz, M J, American fournal of Psychiatry, 1969, 126, 565.

${ }^{4}$ Ungerleider, J T, Fisher, D D, and Fuller, M, fournal of the American Medical Association, 1966, 197, 389.

5 Tennant, F S, and Groesbeck, C J, Archives of General Psychiatry, 1972, 27, 133.

(Accepted 20 March 1979)

Department of Psychiatry, Withington Hospital, Manchester M20 8LR

C BENJAMIN, BSC, fourth-year medical student, Manchester University

\section{Steam sterilisation of sandpits infected with toxocara eggs}

Public parks, playgrounds, and children's sandpits contaminated with toxocara-infected faeces of pets poses a public health problem. ${ }^{12}$ Embryonated toxocara eggs may infect man (children forming a badrisk group) and cause the so-called larva migrans syndrome. ${ }^{3}$ Under optimal conditions eggs mature to the embryonated and infectious forms in three weeks, and in the temperate European climate this process occurs only in summer time. For this reason public sandpits are replenished with new sand each year. This laborious and expensive process has only a transient useful effect because contamination is continuous. Hence ideally a cheap method of killing the embryonated eggs and possibly other micro-organisms while leaving the sand in the pit should be employed. For practical and public health reasons chemicals cannot be used, but a good alternative is to heat the sand in the pit, since thick-shelled nematode eggs are destroyed by pasteurisation. ${ }^{4}$ We have tried to sterilise sandpits by steam and report our results.

\section{Methods and results}

Steam at a temperature of $160^{\circ} \mathrm{C}$ and a pressure of about 10 atmospheres was introduced under thick plastic covers. Initially steam treatment was carried out for five hours to ensure that the high temperature had reached the depth of the pit. Samples (weighing 150-300 g) from the surface and from a depth of $40 \mathrm{~cm}$ were collected before and after treatment for examination for toxocara eggs. The latter were isolated by sieving followed by zinc-sulphate flotation and filtration through a Millipore $(5 \mu \mathrm{m})$ filter. Afte counting and assessing the stage of development the eggs were incubated in moist chambers for three weeks at $28^{\circ} \mathrm{C}$, their maturation being examined under the microscope every week.

All samples contained toxocara eggs, most being found in the superficial layer. None of the eggs had undergone any natural development. This was to be expected since we performed the sampling in January. Maturation to the embryonated stage during laboratory incubation at $28^{\circ} \mathrm{C}$ occurred in $30 \%$ of the eggs from the superficial sample taken before treatment. No development took place in eggs after treatment.

Pasteurisation $\left(20 \text { minutes at } 73^{\circ} \mathrm{C}\right)^{4}$ or temperatures of $60^{\circ} \mathrm{C}$ for one

Temperature $\left({ }^{\circ} \mathrm{C}\right)$ in a sandpit at different depths during steaming at $160^{\circ} \mathrm{C}$

\begin{tabular}{crrrrr}
\hline Depth & \multicolumn{5}{c}{ Steaming time in hours } \\
\cline { 2 - 6 } in & 1 & 2 & 3 & 4 & $4 \frac{1}{2}$ \\
\hline 15 & 100 & 100 & 100 & 100 & 100 \\
30 & 42 & 58 & 68 & 74 & 76 \\
45 & 26 & 44 & 60 & 70 & 75 \\
60 & 16 & 34 & 48 & 60 & 66 \\
\hline
\end{tabular}

hour $^{5}$ will kill nematode eggs, and hence possibly treatment time might be reduced. For this reason we monitored the temperature continuously at several points and different depths during steaming. In the superficial layer of the pit (up to $15 \mathrm{~cm}$ ) the temperature reached an equilibrium of $100^{\circ} \mathrm{C}$ within half an hour (table). At lower levels an equilibrium of a lower temperature was reached later. From these data an appropriate steaming time may be calculated. If one hour at $60^{\circ} \mathrm{C}$ is enough to kill the eggs, the treatment time ( $\mathrm{S}$, in hours) should be $\mathrm{S}=\mathrm{d} / 15+1$ (where $\mathrm{d}$ is the depth in centimetres).

\section{Comment}

As well as giving satisfactory results, steaming is very economical, and given all the costs (wages, fuel, water, electricity, etc) cheaper than removing 15 cubic metres of sand. Moreover, treatment can be repeated several times in the warm season and hence safety can be maintained throughout.

1 Borg, O A, and Woodruff, A W, British Medical fournal, 1973, 4, 470

2 British Medical fournal, 1977, 1, 901

3 Beaver, P C, et al, Pediatrics, 1952, 9, 7 .

${ }^{4}$ Liebman, H, Münchner Beiträge zur Abwasser, Fischerei, und Flussbiologie, 1966, 13, 45.

${ }^{5}$ Lunsmann, W, Inaugural dissertation Tierärztliche Fakultät, München, 1972.

(Accepted 12 March 1979)

Laboratory for Pathology, Department of Parasitology, National Institute of Public Health, PO Box 1, 3720 BA Bilthoven, The Netherlands

FivaN KAPEN, ovM, head of department of parasitology

J F FRANCHIMONT, chief technician

Municipality of IJsselstein, Planetenbaan 2, 3402 HP IJsselstein, The Netherlands

G M OTTER, engineer

\section{Extreme hyperphosphataemia causing acute anuric nephrocalcinosis in lymphosarcoma}

Acute hyperphosphataemia occurring during chemotherapy for leukaemia or lymphoma may be accompanied by mild or severe acute renal dysfunction ${ }^{1}$ of uncertain mechanism. We describe a patient affected with lymphosarcoma in whom extreme hyperphosphataemia was followed by anuria with histologically proved nephrocalcinosis, suggesting a direct relationship between the metabolic disorder and the onset of acute renal failure (ARF).

\section{Case report}

A 43-year-old man was admitted to the renal intensive care unit on 15 June 1976 because of ARF. Six years earlier poorly differentiated malignant lymphoma of the lymphocytic type had been diagnosed by histological examination of one of several enlarged cervical lymph nodes; abdominal lymph nodes were enlarged on lymphangiography. Radiation therapy, cyclophosphamide, and vincristine were administered. Thereafter the patient became asymptomatic and remained so until 1976 on maintenance treatment with cyclophosphamide and chlorambucil.

In June 1976 a relapse occurred with diffuse lymphadenopathy, ascites, palpable abdominal masses, and severe pancytopenia. On 10 June 1976 blood urea was $10 \mathrm{mmol} / 1(60 \mathrm{mg} / 100 \mathrm{ml})$, serum creatinine $109 \mu \mathrm{mol} / \mathrm{l}$ $(1.2 \mathrm{mg} / 100 \mathrm{ml})$, potassium $5.5 \mathrm{mmol}(\mathrm{mEq}) / \mathrm{l}$, urate $785 \mu \mathrm{mol} / 1(13.2 \mathrm{mg} /$ $100 \mathrm{ml}$ ), calcium $2.5 \mathrm{mmol} / 1(10 \mathrm{mg} 100 \mathrm{ml})$, and phosphate $1.4 \mathrm{mmol} / \mathrm{l}$ $(4.3 \mathrm{mg} / 100 \mathrm{ml})$. Bone marrow was infiltrated by vacuolated deeply basophilic lymphoblasts ( $80 \%$ of the marrow elements). Allopurinol and urate oxidase were given for two days. On 12 June, while the blood urate concentration was $357 \mu \mathrm{mol} / \mathrm{l}(6 \mathrm{mg} / 100 \mathrm{ml})$, the patient received intravenously cyclophosphamide $(1.2 \mathrm{~g})$, doxorubicin $(100 \mathrm{mg})$, vincristine $(1.5 \mathrm{mg})$, and methylprednisolone $(120 \mathrm{mg})$. No shock or fever was observed over the next few days. On 15 June ascites and oedema of the legs were still present, while abdominal masses and peripheral lymphadenopathy had disappeared. Blood urea was $32.5 \mathrm{mmol} / 1(196 \mathrm{mg} / 100 \mathrm{ml})$, serum creatinine $272 \mu \mathrm{mol} / 1(3.1 \mathrm{mg} / 100 \mathrm{ml})$, and serum potassium $6.7 \mathrm{mmol} / \mathrm{l}$. Urine output was $1.51 /$ day. The same day the patient was admitted to the renal unit. On admission blood urate was $327 \mu \mathrm{mol} / 1(5.5 \mathrm{mg} / 100 \mathrm{ml})$, calcium $1.43 \mathrm{mmol} / 1$ 
$(5.7 \mathrm{mg} / 100 \mathrm{ml})$, and phosphate $7.9 \mathrm{mmol} / 1(24.5 \mathrm{mg} / 100 \mathrm{ml})$. Intravenous urography and retrograde pyelography disclosed regular enlarged kidneys with normal ureters and renal outlines. Haemodialysis was performed a few hours after admission. Thereafter blood calcium concentration was $1.6 \mathrm{mmol} / 1(6.4 \mathrm{mg} / 100 \mathrm{ml})$ and phosphate $6.7 \mathrm{mmol} / 1(20.7 \mathrm{mg} / 100 \mathrm{ml})$. The patient became anuric and underwent dialysis five times between 18 and 25 June. On 24 June serum calcium was $2.25 \mathrm{mmol} / 1(9 \mathrm{mg} 100 \mathrm{ml})$ and phosphate $3.1 \mathrm{mmol} / 1(9.6 \mathrm{mg} / 100 \mathrm{ml})$. The patient died on 27 June from gastrointestinal haemorrhage.

Postmortem renal histological examination (see figure) showed interstitial oedema and dilatation of tubules with flattening and necrosis of tubular epithelium; several tubular lumens were obstructed by crystalline deposits with concentric structure, coloured by von Kossa stain. No lymphomatous infiltrates were found. Glomeruli were normal.

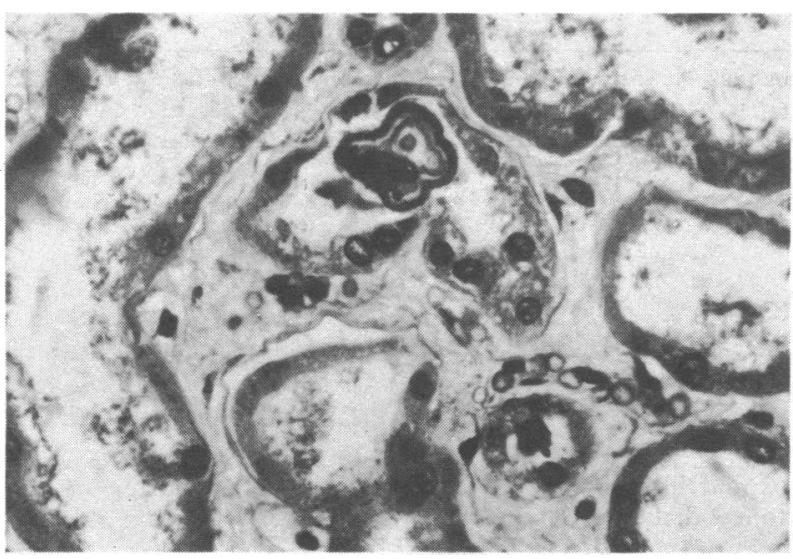

Postmortem renal fragment: stratified calcium deposit in tubule. Degenerative epithelial changes are obvious. (Haematoxylin and eosin. $\times 130$.)

\section{Comment}

As in other reported cases ${ }^{1}$ acute hyperphosphataemia occurred during chemotherapy for lymphoma and was associated with rapid disappeararce of lymphomatous tumours. Hyperphosphataemia was essentially due to drug-induced release of phosphorus from destroyed malignant lymphoblasts, although renal insufficiency may have played a minor part in increasing the serum phosphorus concentration.

Whil : the most usual causes of ARF in malignant lymphomas were excluded, such as hyperuricaemia, ureteral obstruction, and renal tumoral infiltration, characteristic lesions of acute nephrocalcinosis ${ }^{2}$ were found at necropsy. Most probably hyperphosphataemia, with a very hi, sh calcium phosphorus product $(139.65(\mathrm{mg} / 100 \mathrm{ml}))$ favouring extraskeletal calcifications, directly provoked renal lesions and dyifunction. Several facts support this hypothesis. Firstly, in hypercalcaemic patients phosphate infusion may induce ARF with features similar to that observed in our patient-that is, hyperphosphataemia, rapid fall of serum calcium concentration, and nephrocalcinosis. ${ }^{3}$ Secondly, hyperphosphataemia aggravates experimental chronic uraemia through calcium phosphate deposition in the kidneys. ${ }^{4}$ Finally, in keeping with our findings, a recently reported leukae:uic patient had chemotherapy-induced hyperphosphataemia and ARF with the presence of a renal calculus detected by ultrasound. ${ }^{5}$

1 Cadman, E C, Lundberg, W B, and Bertino, J R, American fournal of Medicine, 1977, 62, 283.

${ }^{2}$ Heptinstall, R H, Pathology of the Kidney. Boston, Little Brown, 1974.

3 Carey, R W, et al, Archives of Internal Medicine, 1968, 122, 150.

4 Ibels, L S, et al, New England fournal of Medicine, 1978, 298, 122.

5 Ettinger, D S, et al, fournal of the American Medical Association, 1978, 239, 2472.

(Accepted 20 March 1979)

Service de Nephrologie, Hôpital Tenon, 75020 Paris

ALAIN KANFER, MD, chef de clinique-assistant

GABRIEL RICHET, MD, professeur à la faculté de médecine de ParisSaint Antoine

Service d'Anatomie Pathologique, Hôpital Tenon, 75020 Paris

JEAN ROLAND, MD, professeur à la faculté de médecine de Paris-Saint Antoine

FRANCOIS CHATELET, MD, chef de travaux d'anatomie pathologique

\section{Postcards or outpatients: an alternative method of follow-up}

Conventional outpatient review is both expensive and inefficient: expensive to both the patient and the hospital authority, and inefficient because it fails to discriminate between the patient who is well and the patient who requires further detailed investigation or treatment. Outpatient review can monitor the progress of the patient for his own benefit, provide an analysis of current practice, or simply reassure either patient or doctor.

This study was carried out to determine whether a proforma completed by the patient could accurately reflect the problems and complications occurring after outpatient urological procedures.

\section{Method and results}

A system of pre-paid reply postcards was instituted for patients attending as day cases for urological endoscopy under general anaesthesia (see fig).

Please tick the appropriate box for each of the following questions :-

1. Did you have pain on passing water?

2. Did you have any blood in your water?

3. Did you have to pass water more frequently ?

4. Did you have a shivering attack?

5. Did you have to call out your GP ?

PATIENT'S NAME $\ldots \ldots \ldots \ldots \ldots \ldots$ DATE $\ldots \ldots \ldots \ldots$

The pre-paid reply card.

The questions were designed to assess the occurrence of the most probable complications of the procedures-namely, dysuria, haematuria, frequency of micturition, and rigors-but were described on the cards using non-medical terms. A further question relating to the incidence of medical practitioner call-out was included to give some indication of the subjective response of the patient. A total of 1090 cards was issued. The first 200 patients were given the card after the procedure and were instructed by the nurse in charge to answer the five questions at 24 hours from discharge and then to post the card. In the light of the experience gained from this initial series the subsequent 890 patients had their instructions and explanations reinforced by a member of the medical staff.

In the first series 120 of the 200 cards issued were returned, and in the second series 812 of the 890 cards issued were returned. Eleven patients returned cards with one or more questions unanswered.

\section{Comment}

The potential of reply-paid questionnaires has been shown by Ogg, ${ }^{1}$ Howie and Clark, ${ }^{2}$ and Howie $^{3}$ with response rates of $81-99 \%$. A survey of published work has shown that this system of patientcompleted postal responses has rarely been used in clinical practice.

The discrepancy in response rates between our two series may be attributed to a failure in communication by the staff on issuing the cards. After the initial series one of the medical staff reinforced the instruction to the patients before their discharge from the unit. This gave an immediate rise in the response rate which was maintained throughout the series.

In 1976 the cost to the health authority of an outpatient attendance in a non-teaching acute hospital in England was $f 9 \cdot 22,{ }^{4}$ but there is an appreciable variation in the costs of hospital services throughout the United Kingdom. Such a figure does not take into account the cost of transporting the patient to and from the hospital; any loss of earnings; or loss to the family, employment, or country. At present the total cost of these patient-completed cards including production and postage would not be over $10 \mathrm{p}$ per card.

An adaptation of this system using cards with suitably framed questions could well be used to monitor the progress of patients in many other circumstances. Patients who did not respond, or those who indicated by their reply that further review was appropriate or necessary, would be sent conventional appointments. Although an 